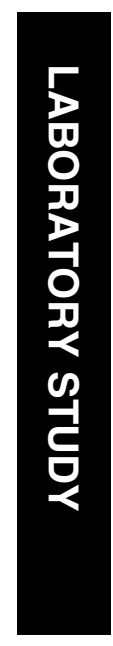

${ }^{1}$ Ocular Oncology Unit, Department of Ophthalmology, University of California at San Francisco, San Francisco, CA, USA

${ }^{2}$ Save Sight Institute and Sydney Eye Hospital, University of Sydney, Sydney, New South Wales, Australia

${ }^{3}$ Comprehensive Cancer Center Biostatistics Core, University of California at San Francisco, San

Francisco, CA, USA

Correspondence: JM O'Brien,

Ocular Oncology Unit, UCSF Department of Ophthalmology, University of California at San Francisco,

10 Koret Way, Box 0730, San Francisco, CA 94143 USA

Tel: + 1415476 0779;

Fax: + 14154760336

E-mail: aleja@

itsa.ucsf.edu

Received: 16 November 2006

Accepted in revised form: 16 January 2007

Published online:

16 March 2007

None of the authors have any commercial or proprietary interest in any of the materials used in this study

\section{Beta-lapachone inhibits proliferation and induces apoptosis in retinoblastoma cell lines}

HR Shah', RM Conway' ${ }^{1,2}$, KR Van Quill' MC Madigan², SA Howard'1', J Qi' ${ }^{1}$ V Weinberg ${ }^{3}$ and JM O'Brien'

\begin{abstract}
Aims To investigate the cytotoxicity of beta-lapachone, a potent agent that may selectively target tumour cells, in retinoblastoma (RB) cell lines.
\end{abstract}

Methods Growth inhibitory effects of betalapachone were evaluated in Y79, WERI-RB1, and RBM human retinoblastoma cell lines. Pro-apoptotic effects of beta-lapachone were evaluated in Y79 cells by detection of caspase 3/7 activity, by enzyme-linked immunosorbent assay for nucleosome fragments, and by cellular morphological analysis.

Results Beta-lapachone induced significant dose-dependent growth inhibitory effects in all three retinoblastoma cell lines. The $50 \%$ growth inhibitory concentration $\left(\mathrm{IC}_{50}\right)$ of this agent was $1.9 \mu \mathrm{M}$ in $\mathrm{Y} 79$ cells, $1.3 \mu \mathrm{M}$ in WERI-RB1 cells, and $0.9 \mu \mathrm{M}$ in RBM cells. Beta-lapachone also induced proapoptotic effects in RB cells. Treatment of Y79 cells with $1.9 \mu \mathrm{M}$ beta-lapachone $\left(\mathrm{IC}_{50}\right)$ resulted in a peak, fourfold induction of caspase $3 / 7$ activity at $72 \mathrm{~h}$ post-treatment; a peak, 5.6-fold increase in nucleosome fragments at $96 \mathrm{~h}$ posttreatment; and a peak, 1.7-fold increase in the frequency of apoptotic cells at $48 \mathrm{~h}$ posttreatment, relative to vehicle-treated controls. Conclusion Beta-lapachone induced potent cytotoxic effects in RB cell lines at low micromolar concentrations, suggesting this agent could be useful in the clinical management of $\mathbf{R B}$.

Eye (2008) 22, 454-460; doi:10.1038/sj.eye.6702764; published online 16 March 2007

Keywords: retinoblastoma; beta-lapachone; drug evaluation, preclinical; cell lines

\section{Introduction}

Retinoblastoma (RB) is the most common primary intraocular malignancy of childhood, affecting 1 in 15000 children. ${ }^{1}$ The disease is caused by loss of function of both alleles of the $\mathrm{RB}$ tumour suppressor gene (RB1) in retinal progenitor cells. Children with the heritable form of this disease carry one mutated $R B 1$ allele in their germ line, and loss of the remaining allele occurs somatically in developing retinal cells. These children typically develop bilateral, multifocal retinal tumours, and they are also predisposed to develop second primary tumours later in life, particularly bone and soft-tissue sarcomas. ${ }^{2}$ RB also occurs in a nonheritable form, in which biallelic inactivation of $R B 1$ occurs somatically in a single retinoblast. In this form of the disease, retinal tumour development is invariably unifocal and unilateral.

RB usually develops in children under 6 years of age, and those who do not receive treatment die within 2-4 years after diagnosis. Although RB has the capacity to invade the brain through the optic nerve and to metastasize hematogenously, it has become one of the most curable pediatric solid tumours in developed countries. An overall survival rate between 90 and 95\% can be achieved with combinations of chemotherapy, external beam radiotherapy, plaque radiotherapy, laser photocoagulation, cryotherapy, and enucleation. ${ }^{3}$ In the developing world, however, RB remains a frequently fatal disease.

Significant long-term morbidity and even secondary mortality have been associated with the application of traditional therapy. External 
beam radiotherapy induces midfacial hypoplasia, retinopathy, optic neuropathy, early cataract formation, and increased incidence of second tumours within the radiation field in children with heritable $\mathrm{RB}^{2,4,5}$ For this reason, chemotherapy with local therapy has become the preferred treatment option for this disease in recent years. ${ }^{6}$ The current standard chemotherapeutic regimen for $\mathrm{RB}$ includes carboplatin, etoposide, and vincristine $(\mathrm{CEV})$. These agents have been associated with adverse effects in some patients including febrile episodes, cytopenia, neutropenia, infections, gastrointestinal distress, and vincristine neurotoxicity. ${ }^{7-11}$ Etoposide and carboplatin are also mutagenic. Etoposide therapy is associated with risk for acute myelocytic leukaemia, ${ }^{12}$ and secondary leukaemias have so far been reported in two RB patients treated with etoposide. ${ }^{13,14}$ Carboplatin may also act synergistically with etoposide in the induction of secondary leukaemias. ${ }^{15,16}$ Because these agents are mutagenic, both of these drugs have potential to exacerbate second tumour risk in children with heritable disease.

Beta-lapachone is a natural $o$-naphthoquinone derived from the bark of the South American lapacho tree (Tabebuia avellanedae). This agent induces potent cytotoxic effects in a wide variety of malignant human cell types, including colon, lung, prostate, breast, pancreatic, ovarian, and bone cancers, as well as leukaemia, melanoma, and malignant glioma. ${ }^{17-22}$ Beta-lapachone appears to exert a spectrum of anticancer effects, resulting in both apoptotic ${ }^{20,23,24}$ and necrotic ${ }^{17,19}$ cell death. Beta-lapachone can directly inhibit DNA topoisomerases I and $\mathrm{II}^{25,26}$ and induce G1- and/or S-phase cell-cycle delay followed by apoptosis or necrosis. ${ }^{17,18,23}$ Beta-lapachone cytotoxicity may also be mediated by the activity of the NAD(P)H:quinone oxidoreductase enzyme NQO1. ${ }^{27}$ This agent has also been shown to selectively induce apoptosis in breast and prostate cancer cells but not in untransformed cells through a mechanism that appears to involve selective induction of the transcription factor E2F1, a regulator of both S-phase progression and apoptosis. ${ }^{24}$ To our knowledge, the effects of beta-lapachone in RB cell lines have not yet been investigated.

In this study, we tested the growth inhibitory effects of beta-lapachone in vitro in Y79, WERI-RB1, and RBM human retinoblastoma cell lines. Growth inhibitory effects of etoposide were also evaluated in Y79 cells and compared with those of beta-lapachone. The proapoptotic effects of beta-lapachone were evaluated by detection of caspase 3/7 activity, by enzyme-linked immunosorbent assay for nucleosome fragments, and by cellular morphological analysis.

\section{Materials and methods}

\section{Agents}

Beta-lapachone (Sigma Chemical Company, St Louis, MO, USA) was dissolved in a $20 \mathrm{mM}$ dimethylsulphoxide (DMSO) stock solution and stored in aliquots at $-20^{\circ} \mathrm{C}$. Etoposide (intravenous injection formulation, Gensia Sicor Pharmaceuticals, Irvine, CA, USA) was purchased from the UCSF Inpatient Pharmacy and diluted in RPMI-1640 media immediately before use.

\section{Cell lines}

Y79, WERI-RB1 (UCSF Cell Culture Facility), and RBM (provided by MCM) human RB cell lines were used in these studies. Cell lines were maintained in RPMI-1640 media supplemented with $15 \%$ fetal bovine serum and $1 \%$ penicillin/streptomycin at $37^{\circ} \mathrm{C}$ in a humidified $5 \%$ $\mathrm{CO}_{2}$ atmosphere.

\section{Growth inhibition assay}

Y79, WERI-RB1, and RBM cells were seeded in ninety-six-well microtiter plates (10000 cells/well) and treated with $0.1-10 \mu \mathrm{M}$ beta-lapachone or with vehicle control (0.1\% DMSO). Y79 cells were also treated with 0.2-20 $\mu \mathrm{M}$ etoposide. Vehicle control for etoposide assays consisted of anhydrous citric acid, polysorbate 80, polyethylene glycol, and dehydrated alcohol. Treated cells were maintained at $37^{\circ} \mathrm{C}$ for $96 \mathrm{~h}$. At $96 \mathrm{~h}$ post-treatment, WST-1 Cell Proliferation Reagent (Roche, Indianapolis, IN, USA) was added to each seeded well and cells were incubated for an additional hour. Absorbance values were then measured in a VersaMax Microplate Reader (Molecular Devices, Sunnyvale, CA, USA). Absolute cell counts were calculated using a standard absorbance curve, and results were expressed as a percentage of vehicle-treated control values. All experiments were performed in triplicate.

\section{Quantification of apoptosis by detection of caspase 3/7 activity}

Ninety-six-well microtiter plates were seeded with Y79 cells as described above and treated with $1.9 \mu \mathrm{M}$ beta-lapachone (the $50 \%$ cell growth inhibitory concentration $\left(\mathrm{IC}_{50}\right)$ of this agent in Y79 cells, as determined by growth inhibition assay). At 8, 24, 48, 72, and $96 \mathrm{~h}$ post-treatment, Caspase-Glo 3/7 Reagent (Promega, Madison, WI, USA) was added to each seeded well and cells were incubated for an additional hour. Resulting luminescence values were measured in an 
Lmax luminometer (Molecular Devices), and results were expressed as fold-induction relative to vehicletreated controls.

\section{Quantification of apoptosis by enzyme-linked} immunosorbent assay for nucleosome fragments

Ninety-six-well microtiter plates were seeded with Y79 cells as described above and treated with $1.9 \mu \mathrm{M}$ beta-lapachone. At 24, 48, 72, and $96 \mathrm{~h}$ post-treatment, nucleosome enrichment in cytoplasmic cell fractions was quantified by Cell Death Detection ELISA Plus assay (Roche) as per manufacturer's instructions. Results were expressed as fold-increase relative to vehicle-treated control values.

\section{Cellular morphology analysis}

Y79 cells were treated in flasks at a density of 200000 cells $/ \mathrm{ml}$ with $1.9 \mu \mathrm{M}$ beta-lapachone. At 24,48 , and $72 \mathrm{~h}$ post-treatment, cells were fixed in $3.7 \%$ paraformaldehyde, seeded into eight-well poly-L-lysinecoated chamber slides, and incubated for $30 \mathrm{~min}$. Plated cells were then treated with $0.5 \%$ Triton X-100 for $5 \mathrm{~min}$ and stained with Hoechst 33258 (Sigma, St Louis, MO, USA) for $30 \mathrm{~min}$ at $37^{\circ} \mathrm{C}$. Slides were then mounted with coverslips and viewed under a fluorescent microscope. For each time point, a representative chamber was selected, and all cells in that chamber were counted and categorized by morphological appearance according to previously described criteria ${ }^{28}$ (http:/ / www.cyto. purdue.edu/cdroms/flow/vol4/index.htm). Cell viability was also evaluated at each time point by trypan blue exclusion assay with manual cell counting. All experiments were performed in triplicate.

\section{Statistical analysis}

Analysis of variance methods were used to determine the significance of mean dose-dependent growth inhibitory effects of beta-lapachone in Y79, Weri-RB1, and RBM cell cultures. Regression analyses were used to estimate the best fit for the linear component of the dose-response curve. The maximum $R^{2}$-value identified the range of concentrations to include in the calculation. $\mathrm{The} \mathrm{IC}_{50}$ was determined from the regression equation for each of the three cell lines.

\section{Results}

\section{Beta-lapachone induces significant dose-dependent growth inhibition in $R B$ cell lines}

Beta-lapachone significantly inhibited proliferation of WERI-RB1 and RBM cells in a dose-dependent manner at $96 \mathrm{~h}$ post-treatment $(P<0.0001$ for each cell line,

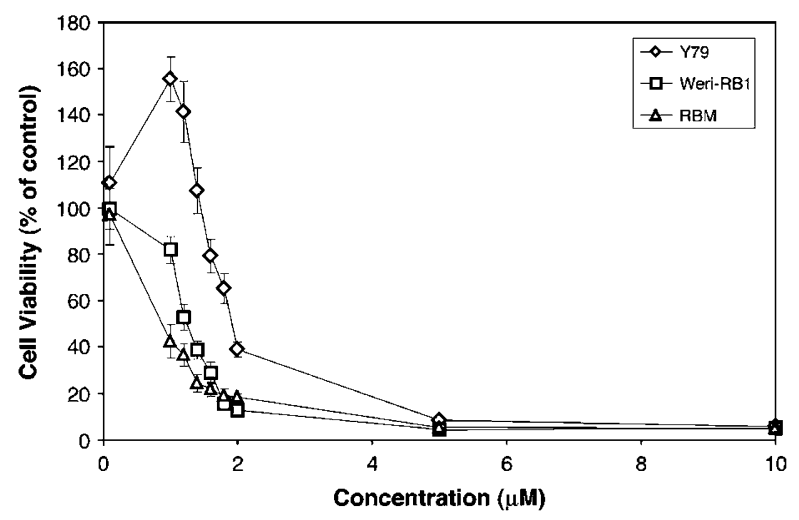

Figure 1 Growth inhibitory effects of beta-lapachone in RB cell lines at $96 \mathrm{~h}$ post-treatment. The $\mathrm{IC}_{50}$ of beta-lapachone was $1.3 \mu \mathrm{M}$ in Weri-RB1 cells, $0.9 \mu \mathrm{M}$ in RBM cells, and $1.9 \mu \mathrm{M}$ in $\mathrm{Y} 79$ cells.

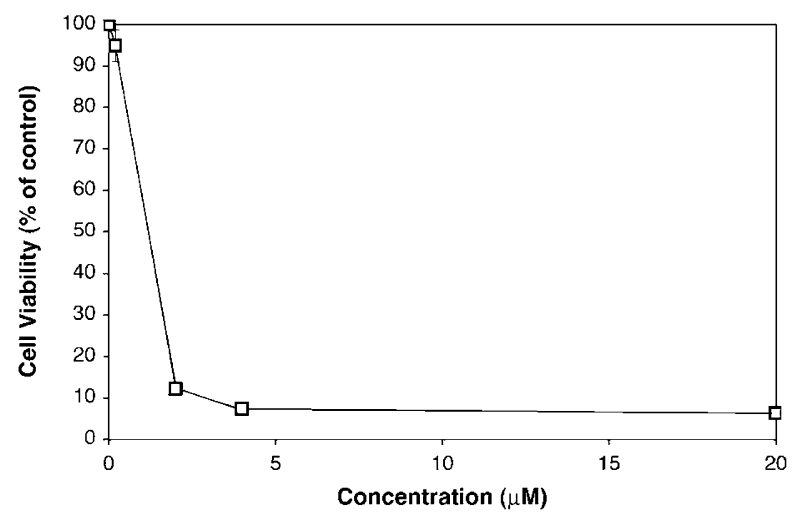

Figure 2 Growth inhibitory effects of etoposide in Y79 cells at $96 \mathrm{~h}$ post-treatment. The $\mathrm{IC}_{50}$ of etoposide was $1.2 \mu \mathrm{M}$, which was similar to the $\mathrm{IC}_{50}$ of beta-lapachone in this cell line.

Figure 1). At the same time point, beta-lapachone also induced significant dose-dependent antiproliferative effects in Y79 cells $(P<0.0001$, Figure 1); however, these effects were observed at concentrations $>1.4 \mu \mathrm{M}$, with enhanced proliferation of Y79 cells observed at lower concentrations, including 1.0 and $1.2 \mu \mathrm{M}$ (Figure 1). The $\mathrm{IC}_{50}$ of beta-lapachone was $1.3 \mu \mathrm{M}$ in WERI-RB1 cells, $0.9 \mu \mathrm{M}$ in RBM cells, and $1.9 \mu \mathrm{M}$ in Y79 cells. By comparison, we found that etoposide also induced dose-dependent antiproliferative effects at low micromolar concentrations in Y79 cells (Figure 2). The $\mathrm{IC}_{50}$ of etoposide was $1.2 \mu \mathrm{M}$, similar to the $\mathrm{IC}_{50}$ of beta-lapachone in Y79 $(1.9 \mu \mathrm{M})$ and other RB cell types (see above).

\section{Beta-lapachone induces proapoptotic effects in Y79 RB cells}

To determine whether the antiproliferative effects of beta-lapachone were mediated by induction of apoptosis, 


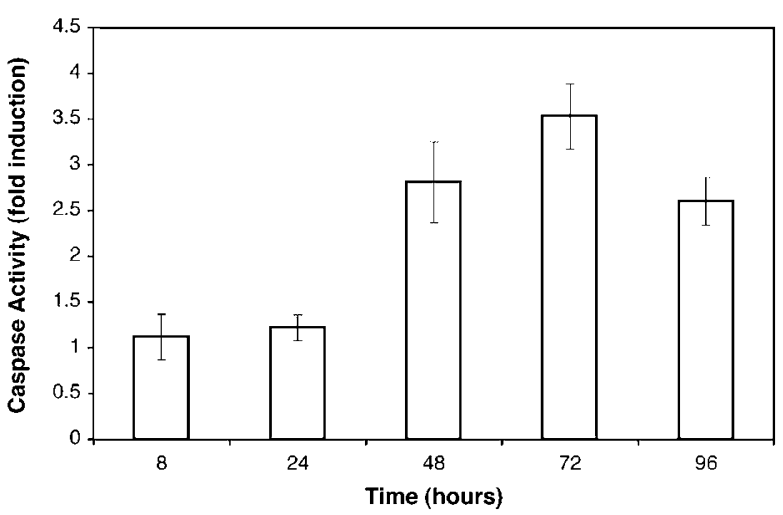

Figure 3 Caspase $3 / 7$ activation in Y79 cells treated with $1.9 \mu \mathrm{M}$ beta-lapachone. Beta-lapachone induced apoptosis-associated caspase $3 / 7$ activity, which increased to 3.5 times vehicle-treated control values at $72 \mathrm{~h}$ post-treatment on average.

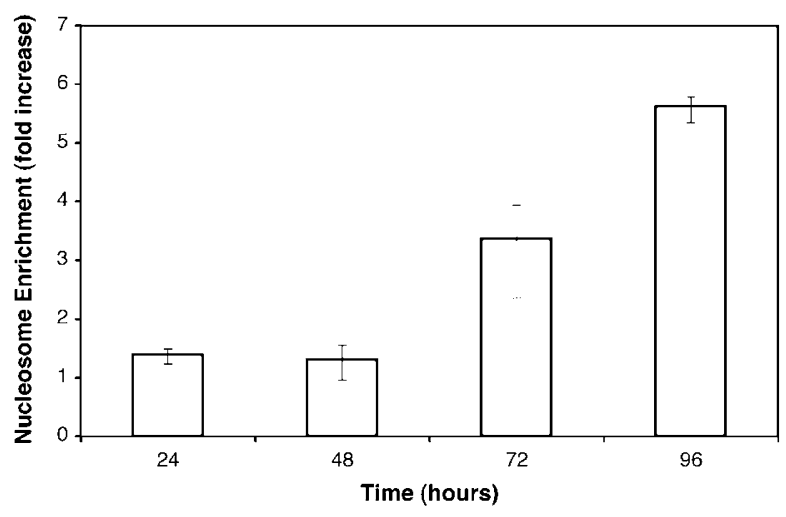

Figure 4 Cytoplasmic nucleosome enrichment in Y79 cells treated with $1.9 \mu \mathrm{M}$ beta-lapachone. Beta-lapachone induced apoptosis-associated intranucleosomal fragmentation, which increased to 5.6 times vehicle-treated control values at $96 \mathrm{~h}$ post-treatment on average.

we assayed beta-lapachone-treated Y79 cells for the activities of caspases 3 and 7, which are markers for apoptosis but not necrosis. Y79 cells treated with $1.9 \mu \mathrm{M}$ beta-lapachone showed a marked increase in caspase activity (Figure 3). At $72 \mathrm{~h}$ post-treatment, the mean caspase activity in beta-lapachone-treated cells was 3.5 times higher than in vehicle-treated controls (Figure 3).

We also quantified the degree of apoptosis-associated intranucleosomal DNA fragmentation in Y79 cells treated with $1.9 \mu \mathrm{M}$ beta-lapachone. Consistent with the caspase analysis, we observed an enrichment of cytoplasmic nucleosome fragments beginning at $72 \mathrm{~h}$ post-treatment, which increased to 5.6 times vehicletreated control values at $96-\mathrm{h}$ post-treatment on average (Figure 4).

Morphological analysis of Y79 cells treated with $1.9 \mu \mathrm{M}$ beta-lapachone confirmed an increased frequency of

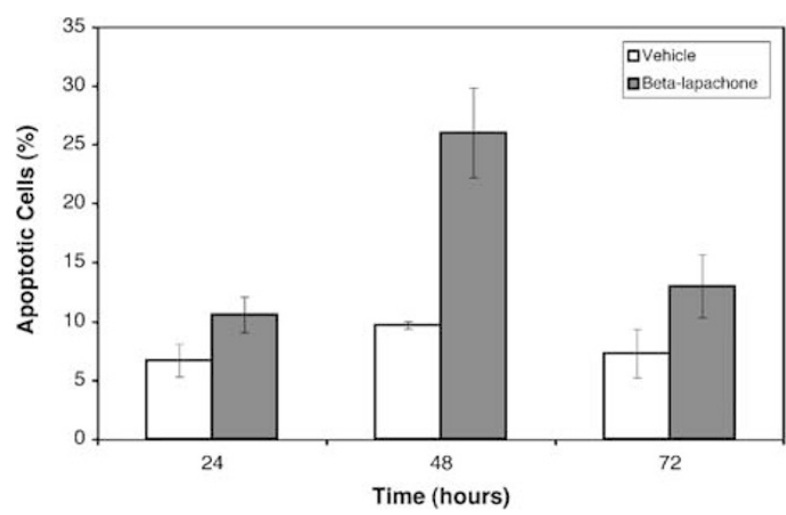

Figure 5 Apoptotic cellular morphology detected by Hoechst staining in Y79 cells treated with $1.9 \mu \mathrm{M}$ beta-lapachone. Beta-lapachone increased the mean per cent of apoptotic cell bodies in Y79 cultures to 1.7 times vehicle-treated control values at 48 -h post-treatment. The mean per cent of apoptotic cells at this time point was $26.0 \pm 3.8$ and $9.7 \pm 0.3 \%$ (mean \pm SD) in treated and control cultures, respectively.

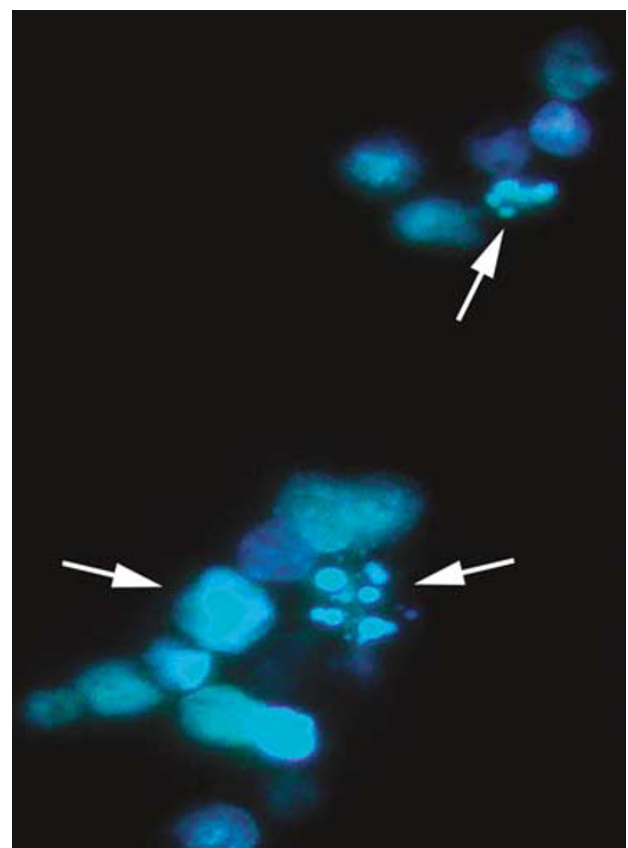

Figure 6 Beta-lapachone-treated Y79 cells demonstrating apoptotic cellular morphology (arrows) by Hoechst staining. Cells were treated with $1.9 \mu \mathrm{M}$ beta-lapachone for $48 \mathrm{~h}$.

apoptotic cells relative to vehicle-treated controls (Figures 5 and 6). The frequency of cells with obvious apoptotic morphology (nuclear condensation and fragmentation, and cytoplasmic condensation) peaked at $48 \mathrm{~h}$ post-treatment, reaching 1.7 times control values on average. The mean per cent of apoptotic cells at this time point was $26.0 \pm 3.8 \%$ (mean \pm SD) in beta-lapachonetreated cells, compared with $9.7 \pm 0.3 \%$ in control cultures 
(Figure 5). Trypan blue analysis showed that reductions in cell viability peaked at $72 \mathrm{~h}$ post-treatment $(54 \%$ of control, data not shown). Beginning at $72 \mathrm{~h}$ posttreatment, we also observed a large increase in the per cent of degenerate cells that took up Hoechst stain $(29.7 \pm 2.5 \%$ in treated cultures vs $8.6 \pm 2.6 \%$ in control cultures, data not shown). These cells displayed advanced degeneration of the nucleus and stained faintly with Hoechst.

\section{Discussion}

In the present study, beta-lapachone induced dose-dependent growth inhibition at low micromolar concentrations in all three RB cell lines tested, consistent with observations in other cancer cell lines. ${ }^{17-22}$ We subsequently confirmed that growth inhibition was mediated, at least in part, by induction of apoptosis, as indicated by increased caspase $3 / 7$ activity and intranucleosomal fragmentation. In addition, beta-lapachone-treated Y79 RB cells displayed cellular morphology characteristic of apoptosis, including chromatin condensation, nuclear fragmentation with bleb formation, and pyknotic bodies ${ }^{28}$ (http:/ / www.cyto.purdue.edu/cdroms/flow/vol4/index.htm). At $72 \mathrm{~h}$ post-treatment, we noted the appearance of a significant number of degenerate cells that could not be characterized definitively, as reported previously. ${ }^{29}$ These degenerate cells were infrequently observed at the earlier time points ( 24 and $48 \mathrm{~h}$ post-treatment), suggesting late-stage degeneration characteristic of apoptosis in cultured cells. ${ }^{29}$

Beta-lapachone has recently been reported to induce apoptosis selectively in breast and colon cancer cells, but not in untransformed breast or colon epithelial cells. ${ }^{24}$ Low micromolar concentrations of beta-lapachone have also been observed to profoundly inhibit proliferation of myeloma cells with no apparent effect on normal peripheral blood mononuclear cells at the same concentrations, further indicating an unusual selectivity of beta-lapachone against cancer cells. ${ }^{30}$

The induction of apoptosis in breast and colon cancer cells by beta-lapachone has been reported to involve selective and rapid induction of the cell-cycle regulating factor, E2F1. ${ }^{24}$ E2F1 is one of the 'activating' members of the E2F family of transcription factors, which, along with E2F2 and E2F3, can induce a large set of genes required for S-phase progression. ${ }^{31,32} \mathrm{E} 2 \mathrm{~F} 1$ has been found to regulate both cellular proliferation and apoptosis, depending on the levels of E2F1 expressed. Higher levels of E2F1 appear to be required for apoptosis induction than for S-phase entry. ${ }^{31-33}$

Other studies in prostate and breast cancer cells have reported that beta-lapachone-induced apoptosis can occur through a mechanism involving NQOI-mediated cycling of this agent. ${ }^{27,34,35} \mathrm{NQOI}$ is an enzyme that reduces quinone-containing agents such as beta-lapachone to more reactive forms. NQO1-deficient prostate cancer cells, and prostate and breast cancer cells treated with dicoumarol (an NQO1 inhibitor) are significantly more resistant to apoptosis than NQO1-expressing prostate cells after beta-lapachone exposure. ${ }^{27,34}$ Furthermore, transfection of NQO1-deficient cells with an NQO1 expression plasmid markedly enhanced sensitivity to beta-lapachone. ${ }^{27,34}$ However, blocking of NQO1 in various cancer cell types does not completely abrogate apoptosis, and although NQO1 plays a major role in beta-lapachoneinduced apoptosis, alternate pathways also appear to be involved. $27,34,35$

Although our experiments were limited to evaluating the cytotoxic effects of beta-lapachone alone in RB cells, a number of studies have found significant synergistic effects of beta-lapachone with other chemotherapeutic agents. ${ }^{18,35-37}$ Beta-lapachone induces G1/S checkpoint delay before inducing cell death, and remarkable in vitro and in vivo synergistic effects have been observed when this agent is administered in combination with taxol, which arrests cells in G2/M. ${ }^{18}$ Beta-lapachone has also been reported to enhance the cytotoxicity of alkylating agents in vitro, possibly owing to beta-lapachone-induced inhibition of DNA repair. ${ }^{37}$ Other studies have demonstrated that beta-lapachone can be effective as a single agent in cross-resistant cell lines. ${ }^{30,38}$ The chemosensitizing effects of beta-lapachone could have application in the clinical management of $\mathrm{RB}$, where chemotherapeutic resistance is frequently observed. Interestingly, beta-lapachone also acts synergistically with ionizing radiation in suppressing tumour growth in vivo, owing to radiation-induced upregulation of NQO1 activity in cancer cells. ${ }^{39}$

In our review of the literature, we found surprisingly few reports on the in vivo toxicity of beta-lapachone. In one study of a mouse model of human ovarian cancer, beta-lapachone administered intraperitoneally in an oil-based vehicle at doses up to $50 \mathrm{mg} / \mathrm{kg}$ (10 cycles, q.o.d.) induced significant antitumour effects with no reported systemic toxicity. ${ }^{18}$ Consistent yet more complete toxicity data have been reported in normal mice receiving intraperitoneal injections of betalapachone in beta-cyclodextrin inclusion complexes on a similar schedule. ${ }^{40}$ No toxicity was observed in mice treated with $50 \mathrm{mg} / \mathrm{kg}$ beta-lapachone in beta-cyclodextrin/water. However, 85 and $100 \%$ lethality was observed in mice treated with 60 and $70 \mathrm{mg} / \mathrm{kg}$, respectively. Interestingly, preliminary investigations of mice that died in that study have been unable to detect major damage to vital organs. ${ }^{40}$ 
The potent cytotoxic effects of low doses of beta-lapachone in RB cells observed in the present study and the recently reported high degree of selectivity of beta-lapachone towards cancer cells in general suggest that beta-lapachone could have utility in the treatment of RB. To better evaluate efficacy and toxicity of this agent, we are currently conducting in vivo studies in a transgenic murine model of this disease.

\section{Acknowledgements}

This study was supported by National Health and Medical Research Council Grant, Canberra, Australia (RMC), Grant EY13812 (JMO) and core Grant EY02162 from the National Eye Institute, Bethesda, MD, That Man May See Inc., San Francisco, CA (JMO), and a Physician-Scientist Award from Research to Prevent Blindness, New York, NY (JMO).

\section{References}

1 Vogel F. Genetics of retinoblastoma. Hum Genet 1979; 52: $1-54$.

2 Eng C, Li FP, Abramson DH, Ellsworth RM, Wong FL, Goldman MB et al. Mortality from second tumors among long-term survivors of retinoblastoma. J Natl Cancer Inst 1993; 85: 1121-1128.

3 Yanagisawa T. Systemic chemotherapy as a new conservative treatment for intraocular retinoblastoma. Int J Clin Oncol 2004; 9: 13-24.

4 Pradhan DG, Sandridge AL, Mullaney P, Abboud E, Karcioglu ZA, Kandil A et al. Radiation therapy for retinoblastoma: a retrospective review of 120 patients. Int Radiat Oncol Biol Phys 1997; 39: 3-13.

5 Wong FL, Boice Jr JD, Abramson DH, Tarone RE, Kleinerman RA, Stovall $\mathrm{M}$ et al. Cancer incidence after retinoblastoma. Radiation dose and sarcoma risk. JAMA 1997; 278: 1262-1267.

6 De Potter P. Current treatment of retinoblastoma. Curr Opin Ophthalmol 2002; 13: 331-336.

7 Levy C, Doz F, Quintana E, Pacquement H, Michon J, Schlienger $\mathrm{P}$ et al. Role of chemotherapy alone or in combination with hyperthermia in the primary treatment of intraocular retinoblastoma: preliminary results. $\mathrm{Br} \mathrm{J}$ Ophthalmol 1998; 82: 1154-1158.

8 Friedman DL, Himelstein B, Shields CL, Shields JA, Needle $\mathrm{M}$, Miller D et al. Chemoreduction and local ophthalmic therapy for intraocular retinoblastoma. J Clin Oncol 2000; 18: 12-17.

9 Beck MN, Balmer A, Dessing C, Pica A, Munier F. First-line chemotherapy with local treatment can prevent external-beam irradiation and enucleation in low-stage intraocular retinoblastoma. J Clin Oncol 2000; 18: 2881-2887.

10 Benz MS, Scott IU, Murray TG, Kramer D, Toledano S. Complications of systemic chemotherapy as treatment of retinoblastoma. Arch Ophthalmol 2000; 118: 577-578.

11 Brichard B, De Bruycker JJ, De Potter P, Neven B, Vermylen C, Cornu G. Combined chemotherapy and local treatment in the management of intraocular retinoblastoma. Med Pediatr Oncol 2002; 38: 411-415.
12 Pui CH, Relling MV. Topoisomerase II inhibitor-related acute myeloid leukaemia. Br J Haematol 2000; 109: 13-23.

13 Nishimura S, Sato T, Ueda H, Ueda K. Acute myeloblastic leukemia as a second malignancy in a patient with hereditary retinoblastoma. J Clin Oncol 2001; 19: 4182-4183.

14 Chantada G, Fandino A, Casak S, Manzitti J, Raslawski E, Schvartzman E. Treatment of overt extraocular retinoblastoma. Med Pediatr Oncol 2003; 40: 158-161.

15 Travis LB, Holowaty EJ, Bergfeldt K, Lynch CF, Kohler BA, Wiklund T et al. Risk of leukemia after platinum-based chemotherapy for ovarian cancer. N Engl J Med 1999; 340: 351-357.

16 Griesinger F, Metz M, Trumper L, Schulz T, Haase D. Secondary leukaemia after cure for locally advanced NSCLC: alkylating type secondary leukaemia after induction therapy with docetaxel and carboplatin for NSCLC IIIB. Lung Cancer 2004; 44: 261-265.

17 Li YZ, Li CJ, Pinto AV, Pardee AB. Release of mitochondrial cytochrome $c$ in both apoptosis and necrosis induced by beta-lapachone in human carcinoma cells. Mol Med 1999; 5: 232-239.

18 Li CJ, Li YZ, Pinto AV, Pardee AB. Potent inhibition of tumor survival in vivo by beta-lapachone plus taxol: combining drugs imposes different artificial checkpoints. Proc Natl Acad Sci USA 1999; 96: 13369-13374.

19 Liu TJ, Lin SY, Chau YP. Inhibition of poly(ADP-ribose) polymerase activation attenuates beta-lapachone-induced necrotic cell death in human osteosarcoma cells. Toxicol Appl Pharmacol 2002; 182: 116-125.

20 Planchon SM, Wuerzberger S, Frydman B, Witiak DT, Hutson P, Church DR et al. Beta-lapachone-mediated apoptosis in human promyelocytic leukemia (HL-60) and human prostate cancer cells: a p53-independent response. Cancer Res 1995; 55: 3706-3711.

21 Chau YP, Shiah SG, Don MJ, Kuo ML. Involvement of hydrogen peroxide in topoisomerase inhibitor betalapachone-induced apoptosis and differentiation in human leukemia cells. Free Radic Biol Med 1998; 24: 660-670.

22 Weller M, Winter S, Schmidt C, Esser P, Fontana A, Dichgans $\mathrm{J}$ et al. Topoisomerase-I inhibitors for human malignant glioma: differential modulation of p53, p21, bax and bcl-2 expression and of CD95-mediated apoptosis by camptothecin and beta-lapachone. Int J Cancer 1997; 73: 707-714.

23 Wuerzberger SM, Pink JJ, Planchon SM, Byers KL, Bornmann WG, Boothman DA. Induction of apoptosis in MCF-7:WS8 breast cancer cells by beta-lapachone. Cancer Res 1998; 58: 1876-1885.

24 Li Y, Sun X, LaMont JT, Pardee AB, Li CJ. Selective killing of cancer cells by beta-lapachone: direct checkpoint activation as a strategy against cancer. Proc Natl Acad Sci USA 2003; 100: $2674-2678$.

25 Li CJ, Averboukh L, Pardee AB. Beta-lapachone, a novel DNA topoisomerase I inhibitor with a mode of action different from camptothecin. J Biol Chem 1993; 268: 22463-22468.

26 Frydman B, Marton LJ, Sun JS, Neder K, Witiak DT, Liu AA et al. Induction of DNA topoisomerase II-mediated DNA cleavage by beta-lapachone and related naphthoquinones. Cancer Res 1997; 57: 620-627.

27 Pink JJ, Planchon SM, Tagliarino C, Varnes ME, Siegel D, Boothman DA. NAD $(\mathrm{P}) \mathrm{H}$ : quinone oxidoreductase activity is the principal determinant of beta-lapachone cytotoxicity. J Biol Chem 2000; 275: 5416-5424. 
28 Malorni W, Fais S, Fiorentini C. Morphological Aspects of Apoptosis. In: A Cossarizza and D Boraschi (eds). Apoptosis: A Laboratory Manual of Experimental Methods, Available online in The Purdue Cytometry CD-ROM Vol 4, J Watson, Guest Ed. JP Robinson, Purdue University Cytometry Laboratories: West Lafayette, IN, 1997. http:// www.cyto.purdue.edu/cdroms/flow/vol4/index.htm.

29 Conway RM, Madigan MC, Penfold PL, Billson FA. Induction of apoptosis by sodium butyrate in the human Y-79 retinoblastoma cell line. Oncol Res 1995; 7: 289-297.

30 Gupta D, Podar K, Tai YT, Lin B, Hideshima T, Akiyama M et al. Beta-lapachone, a novel plant product, overcomes drug resistance in human multiple myeloma cells. Exp Hematol 2002; 30: 711-720.

31 Nahle Z, Polakoff J, Davuluri RV, McCurrach ME, Jacobson MD, Narita $M$ et al. Direct coupling of the cell cycle and cell death machinery by E2F. Nat Cell Biol 2002; 4: 859-864.

32 Trimarchi JM, Lees JA. Sibling rivalry in the E2F family. Nat Rev Mol Cell Biol 2002; 3: 11-20.

33 Ginsberg D. E2F1 pathways to apoptosis. FEBS Lett 2002; 529: 122-125.

34 Planchon SM, Pink JJ, Tagliarino C, Bornmann WG, Varnes $\mathrm{ME}$, Boothman DA. Beta-lapachone-induced apoptosis in human prostate cancer cells: involvement of NQO1/xip3. Exp Cell Res 2001; 267: 95-106.
35 Kumi-Diaka J, Saddler-Shawnette S, Aller A, Brown J. Potential mechanism of phytochemical-induced apoptosis in human prostate adenocarcinoma cells: Therapeutic synergy in genistein and beta-lapachone combination treatment. Cancer Cell Int 2004; 4: 5.

36 Boorstein RJ, Pardee AB. Beta-lapachone greatly enhances MMS lethality to human fibroblasts. Biochem Biophys Res Commun 1984; 118: 828-834.

37 Boothman DA, Trask DK, Pardee AB. Inhibition of potentially lethal DNA damage repair in human tumor cells by beta-lapachone, an activator of topoisomerase I. Cancer Res 1989; 49: 605-612.

38 Dolan ME, Frydman B, Thompson CB, Diamond AM, Garbiras BJ, Safa AR et al. Effects of 1,2-naphthoquinones on human tumor cell growth and lack of cross-resistance with other anticancer agents. Anticancer Drugs 1998; 9: 437-448.

39 Park HJ, Ahn KJ, Ahn SD, Choi E, Lee SW, Williams B et al. Susceptibility of cancer cells to beta-lapachone is enhanced by ionizing radiation. Int J Radiat Oncol Biol Phys 2005; 61: 212-219.

40 Nasongkla N, Wiedmann AF, Bruening A, Beman M, Ray D, Bornmann WG et al. Enhancement of solubility and bioavailability of beta-lapachone using cyclodextrin inclusion complexes. Pharm Res 2003; 20: 1626-1633. 